Mines. This teaching decided the direction of his life's work along the traditional lines of the school of which he was in turn a student, an instructor, and one of the most distinguished professors from the year 1886.

It is a special feature of the French Geological Survey to avail itself of the help of outside professional geologists, such as university professors and teachers, by engaging them during the summer holidays as auxiliary collaborateurs. It is in that way that Marcel Bertrand was induced to carry out during the summer months of several years a series of field observations in the Jura mountains, with the view of publishing detailed geological maps of the region. It was quite natural that the growing interest of the young geologist was excited by the structure of this district-classical for the relative regularity of its foldings.

In I88I Bertrand was led in the same way to investigate the geology of Provence, where a simple appearance hides extreme complexity of structure. It was there that, after several occasional visits to the Alps, he was able to bring new light to bear on the earth's anatomy. He was the first to perceive that the foldings of the pre-Alps have been altered in depth by the older horst of Maure Mountains, and have resulted in extensive overfoldings, which later on have been again obliquely plaited by more recent compression. These investigations culminated in $\mathrm{r} 887$ in the publication of his "Memoire sur le Beausset (Var)," which, notwithstanding its shortness and local character, was received with keen interest by Continental geologists. It was for them the starting point for further inquiries upon new forms of disturbances, and especially upon those long recumbent folds the horizontal extension of which is so great that they are frequently spoken of as sheets.

Bertrand's great experience of the coal mines of the north of France afforded him the opportunity of detecting that overthrusts of the same amplitude had taken place at the close of the Carboniferous period. He expounded these similarities in his memoirs upon "Les Rapports de Structure des Alpes de Glaris et du Bassin Houiller du Nord," where it was suggested, for the first time, that the famous dopple fold of Glaris might be regarded as a single exaggerated overfold coming from the south. This explanation is now accepted by Prof. Heim himself.

In 1896 Bertrand wrote a preface to introduce to the French public a translation of Suess's "The Face of the Earth." If anyone should deny to scientific men the gift of expressing their ideas in a concise and adequate style, reference should be made to this brilliant and lucid account of the progressive development of structural geology from the first attempts of Leopold de Buch and Élie de Beaumont to the synthesis of Suess involving the whole surface of our planet, or the minute re-construction of the former orography of the Highlands by Prof. Lapworth.

In 1896 Bertrand was elected a member of the Académie des Sciences to fill the chair left vacant by the death of Pasteur. In Igoo he took a large part in the organisation of the Paris meeting of the International Geological Congress. He contributed two papers on the geology of the Western Alps, and personally directed one of the excursions in that district. It was the last gratification of his life, for shortly after he suffered great affliction by the death of his daughter, who was buried by a sand-slip when geologising with him.

It is deeply to be regretted that such a gifted man has passed away without having fulfilled his possibilities. He scattered some of his original ideas in short No. I949, VOL. 75] papers which appeared from 1884 until I9oo, chiefly in the Comptes rendus of the French Academy of Sciences, in the Annales des Mines, and in the Bulletin of the Geological Society of Paris. But he did not concentrate his abilities upon a great scientific work which might have been compared to the volumes by Prof. Suess. Our only consolation is the power he possessed to impart his spirit to his students and to the number of his disciples, such as MM. de Launay, Lugeon, Termier, Cayeux, Ritter, \&c., whom he left behind fitted to carry on his work.

\section{M. Allorge.}

\section{H. C. RUSSELL, C.M.G., F.R.S.}

THE announcement of the death of Mr. H. C. Russell, who for nearly forty years was among the foremost representatives of science in the colony of New South Wales, has been received with great regret by many men of science. Since 1870 he held the post of Government astronomer and director of the Sydney Observatory, in succession to Mr. G. R. Smalley, and in that capacity rendered most important services to the colony. His first duty on appointment was to organise the resources of the colony for the observation of the transit of Venus. With small funds, little skilled assistance, and short time for preparation, he nevertheless succeeded in equipping several stations in a highly efficient manner, reflecting great credit upon the readiness of the colonists and the exertions of the observatory staff.

Thenceforward the observatory pursued a course marked by continually increasing usefulness, culminating in the acceptance of a share in the international photographic chart of the heavens. The zone allotted to this observatory extends from $-5^{2}$ to $-64^{\circ}$ declination, and under Mr. Russell's direction the task advanced far towards completion. But in the course of the work it was found that considerable improvement might be effected if the telescope were removed to a station remote from the town of Sydney. The director had long advocated the removal of the observatory, and the mounting of the photographic equatorial at Red Hill probably presages the abandonment of the Sydney site. The measurement of the plates is being prosecuted on a common plan with those taken at Melbourne, and one of the latest papers from Mr. Russell has reference to an improved form of micrometer for the measurement of these plates. Mechanical devices always had great interest for the late director, and he paid great attention to special forms of driving clocks for equatorials.

But most of all the colony is indebted to him for his organisation of the meteorological service. He had charge of a district of the climate of which little was known, and as the colony extended and the population occupied areas of unexplored country, he had to widen the range of his inquiry in order to supply the necessary information to intending settlers. The long series of observations that he published on climate factors, especially those having reference to rain, evaporation, and state of the rivers, attest to his industry, his powers of organisation, and his recognition of the requirements of a young and rising colony. He put it on record that when he assumed office there were but five rain-gauges in the colony. On his retirement there were something like two thousand. His discussion of the results has scarcely been as happy as his collection. $\mathrm{He}$ seems to have relied upon statistical methods rather than on physical facts, and in this way was led to suggest a theory which would make the 
amount of precipitation depend upon the moon's nodes. These cycles are shown very distinctly over the few years that he was able to bring under discussion, but his explanation has not been generally accepted. This is a small matter in comparison with the value of the information which he was able to furnish, and which has contributed in no small degree to the prosperity of the colony. This collection of observations will be of the greatest service in subsequent inquiries.

Mr. Russell has left a character for industry and closeness of application that cannot but prove stimulating to future astronomers in the southern hemisphere. He was much esteemed by many friends in this country, who regretted his retirement from the observatory; and besides being a Fellow of the Royal Society, to which he was elected in 1886 , he was a member of many learned bodies, and was well known as a contributor of frequent and welcome papers.

W. E. P.

\section{DR. ALLAN MACFADYEN.}

BACTERIOLOGICAL science in England has sustained a great loss by the early death of Dr. Allan Macfadyen, who passed away on March $x$, a martyr to that science he loved so well and to which he had devoted his best days, his last illness being caused by accidental infection in the laboratory.

Dr. Macfadyen was a distinguished graduate of Edinburgh University, and subsequently studied at Bern, Göttingen, and Munich. One of his earliest investigations was on the behaviour of the bacteria in the digestive tract, in which he proved that the gastric juice and intestinal secretions protect but little against the invasion of pathogenic microbes. This was soon followed by a joint paper, with Prof. Nencki and Dr. Sieber, on the chemical processes occurring in the small intestine of man, in which the intestinal contents were examined and the exact chemical changes produced by several intestinal microorganisms in pure cultures were studied. With Sir Lauder Brunton, an investigation of the ferment action of bacteria was contributed to the Proceedings of the Royal Society, and his chemical bent was further shown by a paper on the action of bacteria on albumins and peptones, which appeared in the Reports of the Local Government Board. The thermophilic bacteria, organisms which thrive at high temperatures, attracted his attention, and with Dr. Blaxall he carried out an investigation on them in which, almost for the first time, a number of species were differentiated and their action studied. With Dr. Harden, Mr. Rowland, and the late Dr. Morris, researches were conducted on the nature of the yeast zymase of Buchner, and the phosphorescent bacteria and problems of disinfection were other subjects in which he made additions to our knowledge.

Dr. Macfadyen was early inspired with the idea of the paramount importance of the contents and extracts of the unit of life-the cell-and the happy culmination of Sir James Dewar's researches on low temperatures gave him an unlooked-for means of obtaining these in a comparatively unaltered state. He showed that the low temperatures of liquid air and of liquid hydrogen had little or no effect on either the vitality or the functions of microorganisms. With Mr. Rowland he attacked the problem of grinding up bacteria with liquid air, and by a number of ingenious devices he finally succeeded in obtaining the juices of bacteria in sufficient quantity for investigating their characters. The conparative failure of attempts to produce therapeutic sera for such diseases as tuberculosis, typhoid fever, cholera, pneu- monia, \&c., the organisms of which produce little or no extra-cellular toxins, suggested that the juices of these organisms, the "endotoxins," obtained by liquid-air grinding, might be used for immunising. He showed successively that the virulence of an organism varied directly with the amount of endotoxin that could be obtained from it, that an animal might be immunised by means of these endotoxins, and that the serum of such an animal possessed immunising and curative properties.

The application of these principles to the typhoid bacillus, cholera vibrio, pneumococcus, and hog cholera bacillus was described in a series of papers. Latterly, the application of the results to the treatment of human disease occupied Dr. Macfadyen's attention with encouraging prospects, and it is a tragic circumstance that he should be cut off just as his life-work seemed to be nearing completion.

As secretary and head of the Bacteriological Department of the British, Jenner, and Lister Institute of Preventive Medicine, as it was successively named, Dr. Macfadyen had a large share in the organisation of the institute at Chelsea, and much of the bacteriological work that emanated from there was inspired by him. As Fullerian professor of physiology at the Royal Institution, rgor-4, his courses of lectures on the cell, antitoxins, physiology of digestion, and other subjects made him known to a wide circle.

R. T. $\mathrm{H}$

\section{NOTES.}

THE following candidates were selected on Thursday last by the council of the Royal Society to be recommended for election into the society:-Frank Dawson Adams, Hugh Kerr Anderson, William Blaxland Benham, Lord Blythswood, William Henry Bragg, Frederick Daniel Chattawar, Arthur William Crossley, Arthur Robertson Cushny, William Duddell, Fredcrick William Gamble, John Ernest Petavel, Henry Cabourn Pocklington, Henry Nicholas Ridley, Grafton Eiliot Smith, and William Henry Young.

PROF. W. A. TILDEN, F.R.S., has been elected a member of the Athenæum Club under the provisions of the rule of the club which empowers the annual election by the committee of three persons "of distinguished eminence in science, literature, the arts, or for public services."

A DEPUTATION representing the Anthropological Institute, the British Science Guild, and other scientific bodies, waited upon the Prime Minister on Tuesday to urge the establishment of a national anthropometric survey. $\mathrm{Mr}$. R. C. Lehmann, M.P., who introduced the deputation, said that, in the first instance, the survey should have for its object the periodic measurement of children and young people in schools and factories. Besides this, a comprehensive survey of the general population of the whole country should be undertaken. The sum asked for is $4000 l$. or $5000 l$. The need for such a survey was described by Dr. D. J. Cunningham, Mr. J. Gray, Dr. Gow, Sir Lauder Brunton, and Dr. A. C. Haddon. In his reply to the deputation, Sir Henry Campbell-Bannerman confessed that he has been much impressed by the arguments adduced as to the great lack that there is in this country of knowledge of the quality of the population. It is obviously desirable to have a record of the kind proposed in order to be able to study the changes in the condition of the people at large as a guide to action in administration and in legislation regarding it. Any test applied to the condition of the inhabitants of any district is a test of their surroundings, of the mode in which they live

NO. I 949 , VOL. 75 ] 